\title{
O PARFOR E SUA OPERACIONALIZAÇÃO EM MATO GROSSO DO SUL (2009-2011)
}

\author{
Margarita Victoria Rodríguez* \\ Leandro Picolli Nucci** \\ Silvia Helena Andrade de Brito***
}

Resumo: Este artigo teve como objeto a operacionalização do Plano Nacional de Formação de Professores da Educação Básica (Parfor), entre 2009 e 2011, em Mato Grosso do Sul. Para tanto, analisou o Parfor no contexto das políticas de formação de professores dos governos Lula da Silva e Dilma Rousseff, e sua operacionalização em Mato Grosso do Sul, com base em documentos e entrevistas realizadas com seus dirigentes. A análise revela as dificuldades dos cursistas para frequentar os cursos, em razão das precárias condições oferecidas pelo Governo estadual para a adesão de seu quadro docente ao Programa. Nesse sentido, tornou-se responsabilidade dos cursistas a criação de condições para a sua permanência no Programa, descaracterizando-se, portanto, a responsabilidade do Estado com a sua formação.

Palavras-chave: Parfor. Formação de professores. Regime de colaboração.

\section{The Parfor and your operation in Mato Grosso do Sul (2009-2011)}

\begin{abstract}
This article is about the implementation of the National Plan for Training of Basic Education Teachers (Parfor), between 2009 and 2011, in Mato Grosso do Sul. Therefore, it analyzes the Parfor inside the context of the teacher training politics from Governments Lula da Silva and Dilma Rousseff, and its implementation in Mato

\footnotetext{
* Pós-doutora em História da Educação pela Universidade Federal de Minas Gerais; Doutora em Filosofia e História da Educação pela Universidade Estadual de Campinas;; Professora da Universidade Federal de Mato Grosso do Sul; Cidade Universitaria, Campo Grande - MS, 79090-900; poroyan@uol.com.br

*** Mestre em Educação pela Universidade Federal de Mato Grosso do Sul; Doutorando em Educação na Universidade Federal de Mato Grosso do Sul; Licenciado em Filosofia pela Universidade Católica do Bosco; 1pnucci@gmail.com

*** Doutor em Educação pela Universidade Estadual de Campinas; Mestre em Educação pela Universidade Federal de Mato Grosso do Sul; Professora associada III da Universidade Federal de Mato Grosso do Sul; silvia.brito@ufms.br
} 
Grosso do Sul, based on documents and interviews made with its leaders. The analysis shows the difficulties of the course participants to attend courses on account of to the precarious conditions offered by the state Government for the accession of its faculty to the Program. In this sense, become the responsibility of the course participants to create conditions for their stay in the Program, mischaracterizing, therefore, the State's responsibility with their training.

Keywords: Parfor. Teacher training. Collaborative.

\section{INTRODUÇÃO}

O Plano Nacional de Formação de Professores do Magistério da Educação Básica $^{1}$ (Parfor) é um Programa de caráter emergencial e focal lançado em 2009 sob a responsabilidade do Ministério da Educação (MEC). Ele faz parte do Programa “Todos pela Educação", do Plano de Desenvolvimento da Educação (PDE) ${ }^{2}$, e foi estabelecido para cumprir algumas das metas visadas pela política nacional de formação de professores da educação básica. Segundo documentos oficiais (COORDENAÇÃO DE APERFEIÇOAMENTO DE PESSOAL DE NÍVEL SUPERIOR, 2011a), o Parfor tem como objetivo oferecer formação inicial de primeira e segunda licenciaturas, bem como formação pedagógica ${ }^{3}$ para professores que atuam na educação básica $(\mathrm{EB}) \mathrm{da}$ rede pública dos municípios, dos estados e do Distrito Federal, com a finalidade de melhorar a qualidade da EB e, consequentemente, os indicadores do Sistema de Avaliação da Educação Brasileira (SAEB).

De acordo com a Coordenação de Aperfeiçoamento do Pessoal de Nível Superior (Fundação Capes), órgão que executa - pelo MEC - as ações do Programa, o Parfor é resultado da ação conjunta do MEC, das instituições de ensino superior (IESs) - estatais e privadas parceiras - e das secretarias de educação dos estados e municípios, no âmbito do Plano de Metas "Compromisso Todos pela Educação", que estabeleceu um novo regime de colaboração no país, considerando a autonomia dos Entes Federados (BRASIL, 2007a). ${ }^{4}$

$\mathrm{O}$ que se pretendeu neste artigo foi problematizar a operacionalização do Parfor entre 2009 e 2011 no Estado de Mato Grosso do Sul, considerando dois aspectos: como o Parfor se situou no contexto das políticas de formação de professores dos governos Lula da Silva e Dilma Rousseff; e a forma como o Programa foi operacionalizado em Mato Grosso do Sul, destacando-se o acesso dos professores da EB aos cursos ali oferecidos. Para tal, considerando o momento histórico em que ocorreram os processos em discussão e tendo como eixo analítico uma perspectiva de totalida- 
de, ${ }^{5}$ tomam-se como balizas o movimento de reestruturação produtiva no contexto da produção capitalista e as reformas neoliberais implantadas nos Estados nacionais, ambos ocorridos a partir dos anos 1990. Assim, para a análise do Programa, foram considerados documentos referentes à organização e desenho às políticas nacionais de formação de professores e do Parfor, o levantamento e a análise de dados de matrículas e financiamento, bem como dados de entrevistas realizadas com os dirigentes nacionais, estadual e local do Programa.

Para essa análise, o trabalho divide-se em três partes: na primeira, foi realizada uma discussão sobre a forma e o conteúdo das políticas desenvolvidas para a formação de professores, no período entre 2009 e 2011, que abrangeu a segunda gestão do Governo Lula da Silva e parte da primeira gestão do Governo Dilma Rousseff. A segunda parte do artigo tem como objeto a operacionalização do Parfor em Mato Grosso do Sul, em sua dimensão de Programa formador de quadros docentes no Estado, problematizando os entraves enfrentados para a sua implementação. Como conclusão, são retomados os principais elementos analíticos, resultantes das discussões anteriormente elencadas.

\section{AS POLÍTICAS DE FORMAÇÃO DE PROFESSORES NOS GOVERNOS LULA DA SILVA E DILMA ROUSSEF}

Para tratar das políticas de formação de professores nos governos Lula da Silva e Dilma Rousseff, é preciso, inicialmente, considerar as transformações sofridas pelo capitalismo e, em seu interior, pelo Brasil, entre os anos 1990 e a primeira década do século XXI.

Partindo da década de 1970, importa assinalar que, naquele momento histórico, a dinâmica de acumulação do capital entrou em conflito com o Estado intervencionista. ${ }^{6}$ A crise econômica e a redução da atividade produtiva, além de provocarem o desemprego, também colaboraram para a diminuição da receita dos governos e para o déficit fiscal. Com o argumento de que o Estado estava em crise e falido por causa do inchaço causado pelas políticas de proteção social do Welfare State, iniciou-se o desmonte deste por meio de ajustes políticos e institucionais de cunho neoliberal, o que levou à chamada reforma do Estado, denominação que lhe foi atribuída no contexto das políticas neoliberais. Abreu (1999, p. 41) destaca seis características essenciais desse processo: 
1) a desregulamentação da entrada e saída de capitais nos países;

2) a liberalização do comércio com a eliminação das barreiras alfandegárias;

3) a privatização e transnacionalização das empresas públicas;

4) o reconhecimento jurídico das marcas e patentes tecnológicas do capitalismo mundial;

5) a redução dos gastos públicos (portanto, de serviços públicos como saúde, educação, transporte, fundos de aposentadoria e pensão, telefonia, água, energia, etc., que devem ser concedidos e explorados comercialmente pelo capital privado);

6) a desregulamentação das relações de trabalho, retirando-as da esfera pública e submetendo-a às condições do mercado (de domínio privado).

O Estado se submeteu à globalização capitalista, transferindo parte de suas responsabilidades da esfera pública para a iniciativa privada; e do âmbito da soberania nacional para a ordem social mundial capitalista. Assim, conforme a ideologia neoliberal, o Estado deve limitar sua intervenção na vida social à proteção do mercado, sobretudo no plano econômico, cumprindo uma função de regulador/mediador que valoriza a concorrência e a livre iniciativa.

Dentro do quadro apresentado, as políticas sociais nas últimas décadas do século XX e início do século XXI sofreram mudanças na sua configuração. Como os interesses da acumulação ampliada do capital provocaram o desmonte das iniciativas do Estado de bem-estar social e, consequentemente, das políticas sociais universalizantes, estas últimas foram redimensionadas, adquirindo um caráter particular/focal e emergencial, direcionadas às camadas sociais que estariam à margem do mercado de trabalho ou a setores mais vulneráveis da classe trabalhadora.

Embora as reformas neoliberais, na sua totalidade, tenham assumido as tendências anteriormente apresentadas, elas atingiram cada país e região de forma particular. No Brasil, afirmaram-se nos anos 1990 com os governos de Fernando Collor de Mello (1990-1992), Itamar Franco (1992-1995) e Fernando Henrique Cardoso (FHC - 1996-2002) que, pautados pelas orientações do Consenso de Washington, ${ }^{1}$ guiaram o país rumo à sua nova inserção no mercado internacional.

Os ajustes sobre as políticas sociais no Brasil aconteceram, principalmente, nos cortes orçamentários, na redução do quadro de funcionários e nas alterações nos mecanismos de gestão. Esse processo reforçou, no setor estatal, a lógica do setor privado/mercado, ou seja, a racionalidade da eficiência, restrita ao custo-benefício, com a chamada modernização do setor público. O referido ajuste provocou o sucateamento dos serviços públicos (SOARES, 2009) e "O Estado torna-se mais escandalosamente defensor de interesses monopolistas financeiros, abrindo-se para a terceirização de 
serviços e funções, e para a ampliação de fundos de investimentos criados a partir de suas próprias empresas estatais." (PANIAGO, 2012, p. 78).

Tais tendências tiveram continuidade com o Governo de Luiz Inácio Lula da Silva (2003-2010), em que pesem as propostas da Terceira Via. ${ }^{8}$ Ao realizar um balanço da educação no Brasil na primeira década do século XXI, especificamente no Governo Lula, Frigotto (2011) chega à conclusão de que há um movimento de mudança na conjuntura brasileira - na qual se inclui o campo educacional - mas não há alteração no tecido estrutural que rompa com o sistema capitalista vigente pós-década de 1990. O autor parte das opções e embates acerca do projeto societário que marcou a conjuntura da época e, dentro deste, inclui o balanço educacional. A primeira década do século XXI (2003-2010), assim, é explicada na perspectiva da totalidade, tomando-se como parâmetro as formas estruturais, que compõem a organização societal, e as forças sociais que então se materializaram. Nessa direção,

Qualquer que seja o objeto de análise no campo das ciências
humanas e sociais que se queira tratar no plano da historicidade,
vale dizer, no campo das contradições, mediações e determi-
nações que o constituem, implica necessariamente tomá-lo na
relação inseparável entre o estrutural e o conjuntural. Por outra
parte, implica tomar o objeto de análise não como um fator, mas
como parte de uma totalidade histórica que o constitui, na qual
se estabelecem as mediações entre o campo da particularidade
e sua relação com uma determinada universalidade. (FRIGOT-
TO, 2011, p. 236).

Pensado a partir desses marcos teóricos, o Governo Lula também foi determinado pelos limites estruturais do capitalismo, apesar de abrir sua gestão com o Programa Fome Zero, que pretendia combater a miséria. O Programa fez parte do seu discurso de posse, no qual afirmou que todos os brasileiros têm o direito de "tomar café da manhã, almoçar e jantar”. Porém, apesar de apresentar o Programa como uma proposta superadora da iniciativa neoliberal, esta era mais uma iniciativa de caráter focal e emergencial, que continuava atendendo às orientações do Banco Mundial de corte no orçamento do setor público, ou seja, de reduzir os direitos sociais daqueles que estavam em melhores condições e concentrar o gasto estatal nos "socialmente vulneráveis". Por isso, embora os investimentos realizados no campo social tenham aumentado de 12,92\% do PIB em 2002, último ano do Governo FHC, para 15,54\% em 2010, último ano da gestão Lula da Silva (CASTRO, 2012), representando um aumento de 20,3\%, o desenho dessas políticas manteve o caráter emergencial e focal delineado nos anos 1990. Da mesma forma, mantiveram-se tais diretrizes na gestão de Dilma Rousseff, iniciada em 2011. 
Ora, nesse contexto de mudanças ocorridas na sociedade capitalista entre os anos 1990 e 2000, o tema da educação e da formação de professores ganhou destaque. Pode-se dizer que reformas em curso nos governos dos anos 1990 (Collor de Mello, Itamar Franco e FHC) desencadearam dois conjuntos de transformações. Primeiro, o teor das políticas educacionais, definido pelo caráter de reestruturação do Estado e pela mundialização do capital, levou à defesa da proposta de que a escolarização, principalmente, o fortalecimento da educação básica, garantiria ao indivíduo as ferramentas para competir no mercado de trabalho e ascender economicamente. Consequentemente, seria necessária uma nova formação de professores para viabilizar as condições de tal escolarização, visando à inserção produtiva desses alunos/trabalhadores.

Tais demandas e seus pressupostos ideológicos continuaram presentes na década seguinte (governos Lula e Dilma Rousseff), quando cresceu a defesa pelo binômio "educação e desenvolvimento" dentro do contexto da reestruturação produtiva e combinado ao prisma neoliberal. Ou seja, recuperam-se as ideias da social-democracia de que os investimentos em educação, no contexto presente da sociedade capitalista na educação básica, podem favorecer o desenvolvimento ${ }^{9}$ de uma nação. A isso se atrelaria, no entanto, a necessidade de uma formação docente adequada às diretrizes propostas.

Nesse sentido, no primeiro Governo de Luiz Inácio Lula da Silva (20032006) não se observaram grandes mudanças em relação à política anterior para a formação de professores: o caráter emergencial e focal delineado nos anos 1990 foi mantido, intensificando-se as propostas de formação com base no ensino a distância (FREITAS, 2007). Ao mesmo tempo, contudo, foram encetados esforços visando a uma política de formação continuada que fortalecesse a formação inicial e estivesse articulada com ela. ${ }^{10}$ Esse esforço levou a Secretaria de Educação Básica (SEB/MEC), o Departamento de Políticas de Educação Infantil e Ensino Fundamental (DPE) e a Coordenação Geral de Política de Formação (Copfor) a criarem, em julho de 2004, a Rede Nacional de Formação Continuada de Professores da Educação Básica, por meio da celebração de convênios com universidades selecionadas, nos termos do Edital n. 01/2003/MEC (BRASIL, 2005). Cabe ressaltar que durante esse período o Governo privilegiou os convênios com instituições públicas federais e estaduais e apenas participaram desse processo duas instituições privadas comunitárias. $\mathrm{O}$ foco da formação esteve voltado para cinco áreas: Alfabetização e Linguagem; Educação Matemática e Científica; Ensino de Ciências Humanas e Sociais; Artes e Educação Física; e, Gestão e Avaliação da Educação. ${ }^{11}$ 
No contexto dessa Rede, o MEC desenvolveu sua política de formação de professores, baseada nos seguintes programas:

a) Programa de Formação Inicial de Professores em Exercício na Educação Infantil (Proinfantil): criado em 2006, era um curso de nível médio na modalidade semipresencial, com duração de dois anos, destinado a professores sem titulação que atuavam nas creches e pré-escolas das redes públicas - municipais e estaduais — e da rede privada sem fins lucrativos - comunitárias, filantrópicas ou confessionais - conveniadas ou não. Contava com carga horária de 3.200 horas distribuídas em quatro módulos semestrais de 800 horas cada, tendo funcionado até o ano de 2012.

b) Programa de Formação de Professores em Exercício (Proformação): iniciou-se de forma experimental em fevereiro de 1999 nos estados de Mato Grosso e Mato Grosso do Sul, ainda durante o Governo de FHC, no contexto da Política Nacional para Formação e Profissionalização do Magistério definida pelo MEC no período 1995-1998, fundamentado no documento do Conselho Nacional de Secretários de Educação (Consed), Diretrizes para subsidiar a formulação de um Programa de Titulação dos Docentes do Ensino Fundamental. Tratava-se de um curso a distância, de nível médio, com habilitação ao magistério. Era ofertado pelo MEC, em convênio da Secretaria de Educação a Distância (Seed), contando com o apoio do Fundo de Fortalecimento da Educação (Fundescola/Banco Mundial) mediante celebração de parcerias com estados e municípios. Destinava-se a professores que não possuíam habilitação e que atuavam nos anos iniciais do ensino fundamental, nas classes de alfabetização ou na educação de jovens e adultos das redes públicas de ensino do país. O programa certificou 34.207 professores até o final de 2007, em 15 estados.

c) Programa de Formação Inicial para Professores dos Ensinos Fundamental e Médio (Pró-licenciatura): foi implantado em 2005, com a coordenação das Secretarias de Educação Básica (SEBs) e de Educação a Distância (SEEDs) e com o apoio e a participação das Secretarias de Educação Especial (Seesps) e Educação Superior (SESu), no âmbito da Universidade Aberta do Brasil. É um Programa de formação inicial de professores a distância, "[...] oferecido a profissionais que exerçam 
a função docente nos anos finais do ensino fundamental e no ensino médio e que não possuam habilitação específica na área de atuação (licenciatura).” (BRASIL, 2006).

Outra ação que visava à oferta de cursos de formação docente foi a criação do Sistema Universidade Aberta do Brasil, pelo Decreto n. 5.800/2006 (BRASIL, 2006), com o objetivo de ofertar cursos gratuitos de educação superior, na modalidade a distância, com ação prioritária na formação inicial e continuada de professores para a educação básica. O referido Decreto estabelecia que a oferta dos cursos se realizasse mediante convênios e acordos de cooperação entre instituições públicas de ensino superior e Entes Federativos, a serem firmados e realizados por meio de edital, publicado pelo MEC. Destacava, ainda, que se privilegiaria a parceria entre governos Federal, estadual e municipal e instituições de ensino superior.

Registre-se, ainda, durante o primeiro mandato do Presidente Luiz Inácio Lula da Silva, a elaboração e aprovação das Diretrizes Curriculares Nacionais para o Curso de graduação em Pedagogia (licenciatura) aprovadas em 2006, Curso que ainda não contava com diretriz curricular própria (BRASIL, 2006). Por conta da organização do movimento docente e da participação de entidades científicas, verificou-se um avanço em relação à definição das diretrizes para o Curso de Pedagogia, que incorporou a proposta de formação inicial como base para a docência.

Em que pesem essas iniciativas, contudo, o caráter emergencial e focal dos programas ainda aparecia como traço distintivo dessas políticas, que em muitos momentos, inclusive, dirigem-se ao mesmo público-alvo. Nessa perspectiva, no segundo mandato do Governo Lula (2007-2010), verificou-se uma política que pretendia alterar a proposta de formação fragmentária e desordenada que ainda subsistia. Para tanto, intensificam-se os programas e projetos que parecem acentuar em princípio a participação das instituições públicas na formação dos professores.

Para tanto, destacam-se as ações no marco do Plano de Metas Compromisso Todos Pela Educação (Decreto n. 6.094/2007), instituído pela União para funcionar em regime de colaboração e com adesão de estados, Distrito Federal e municípios, efetivado por meio dos Planos de Ações Articuladas (PAR) com foco em quatro dimensões: Gestão Educacional; Formação de Professores e Profissionais de Serviço e Apoio Escolar (Parfor); Práticas Pedagógicas e Avaliação; Infraestrutura Física e Recursos Pedagógicos.

Nesse momento histórico se verifica, ainda, uma mudança substancial que afetou de forma significativa as políticas de formação de professores: foi criada a 
Nova Capes, que assumiu a responsabilidade pela oferta nacional de formação inicial e continuada para professores das escolas públicas brasileiras (Lei n. 11.502/2007).

A referida Lei, no artigo $2^{\circ}$ fixa:

$\S 2^{\circ}$ : No âmbito da educação básica, a Capes terá como finalidade induzir e fomentar [...] a formação inicial e continuada dos profissionais de magistério [...]

$\S 3^{\circ}$ : A Capes estimulará a valorização do magistério em todos os níveis e modalidades de ensino. (BRASIL, 2007b).

Assim, a Capes iniciou um processo no qual passaria a desenvolver ações que focassem a formação inicial de professores, especialmente porque se verificava a falta de docentes qualificados para atuar em disciplinas, como: Física, Química, Matemática e Biologia. Assim, mediante o Decreto n. 6.755/2009 (BRASIL, 2009a) foi instituída a Política Nacional de Formação dos Profissionais do Magistério da Educação Básica, com o objetivo de organizar e fomentar a formação inicial e continuada dos profissionais do magistério das redes públicas da educação básica. Tais diretrizes foram sistematizadas no Plano Nacional de Formação dos Professores da Educação Básica, por meio de Portaria do MEC (Portaria Normativa n. 9, de 30 de junho de 2009 (BRASIL, 2009b).

Destaque-se ainda que, embora definido como um programa emergencial, o Parfor continua sendo desenvolvido pelo Governo Dilma Rousseff (2011-2014), quando se realizaram o I Encontro Nacional do Parfor, em setembro de 2011; e foram consolidados os Fóruns Estaduais Permanentes de Apoio à Formação Docente, criados em 2009 com o objetivo de serem responsáveis pelo cumprimento das políticas nacionais de formação docente, em que se situa o Parfor. Dessa forma, a implementação do Parfor em Mato Grosso do Sul será o elemento a ser apresentado na próxima seção deste trabalho.

\section{AS PROPOSTAS E A IMPLEMENTAÇÃO DO PARFOR EM MATO GROSSO DO SUL}

Nesse contexto, o Parfor foi lançado em 2009 como uma política governamental voltada para a melhoria da educação básica. Oferecendo cursos presenciais e a distância e trazendo as marcas da conjuntura política na qual estava inserido, configurou-se como outra política focal e emergencial visando aumentar o nível de formação dos docentes da educação básica. 
Para tal, no período de 2009 a 2011, o Parfor ofertou 175.451 vagas, mas o número de matrículas foi de 46.626; e foram abertas 1.409 turmas especiais. O Gráfico 1 demonstra a distribuição, por região, das matrículas nos cursos de formação inicial na modalidade presencial e permite uma visão panorâmica do Parfor em todo o território nacional.

Gráfico 1 - Distribuição das matrículas do Parfor por região - 2009 a 2011

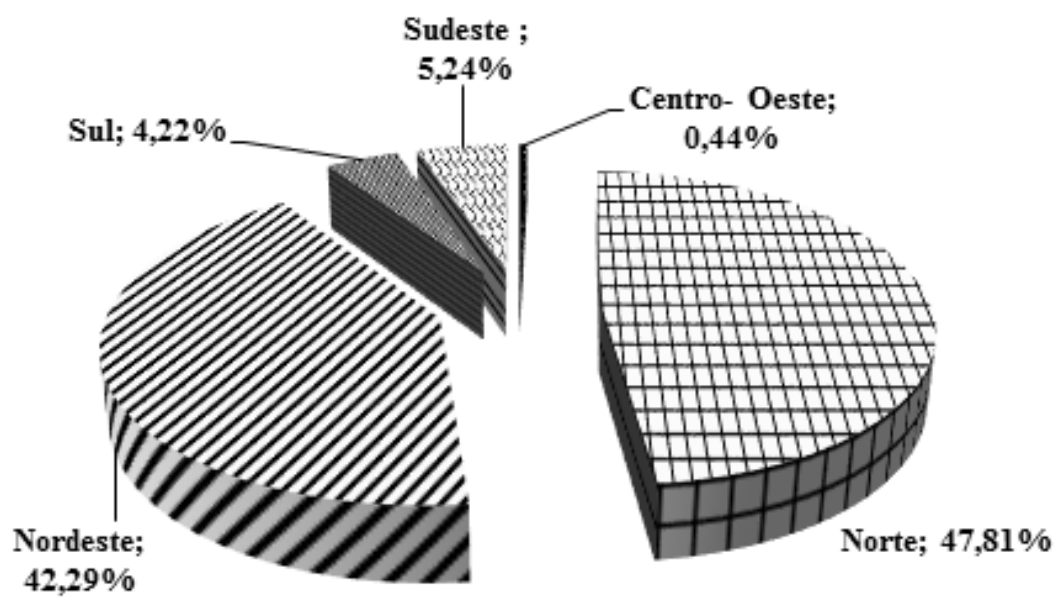

Fonte: Coordenação de aperfeiçoamento de Pessoal de Nível Superior (2012a).

Observa-se que as regiões Norte e Nordeste juntas detiveram 90,1\% das matrículas e as outras regiões juntas representam 9,9\% delas. A região Centro-Oeste apresentou o menor percentual, $0,44 \%$ de matrículas, e a região Norte o maior, 47,81\%. A diferença entre essas regiões foi bastante expressiva, embora acompanhe os dados relativos às desigualdades regionais, considerando inclusive os candidatos em potencial para o programa: em 2009, do total de professores da EB existentes na região Norte, $46 \%$ não possuíam o ensino superior; para a região Nordeste esse percentual era de 51\%; para a região Sudeste, 21\%; para a região Sul, 21\%; e para a região Centro-Oeste, $20 \%$ (INSTITUTO NACIONAL DE ESTUDOS E PESQUISAS EDUCACIONAIS ANÍSIO TEIXEIRA, 2013). ${ }^{12}$

No período de 2009 a 2011, em nível nacional, foram abertas mais de 1.438 turmas especiais presenciais e as matrículas atingiram o número de 47.153. Destas, 90\% se concentraram em cursos de primeira licenciatura; para os cursos de segunda licenciatura, o percentual foi de $9,8 \%$, e para os cursos de formação pedagógica, o per- 
centual foi de 0,20\% (COORDENAÇÃO DE APERFEIÇOAMENTO DE PESSOAL DE NÍVEL SUPERIOR, 2014).

O fomento dos cursos do Parfor presencial ocorreu mediante a implantação de turmas especiais nos cursos de licenciaturas das IESs parceiras. O inciso II do artigo $2^{\circ}$ da Portaria Normativa n. 9, de 30 de junho de 2009 (BRASIL, 2009b), previa o fomento às IESs para apoio à oferta de cursos de licenciaturas, de formação continuada e de programas especiais. Os repasses seriam concedidos pela Capes e pelo Fundo Nacional de Desenvolvimento da Educação (FNDE).

Os cursos ofertados nas IESs parceiras são coordenados e ministrados pelos professores efetivos dessas instituições, que recebem um auxílio financeiro na modalidade de bolsa, financiada pela Capes. ${ }^{13}$ Ressalta-se, no entanto, que os professores cursistas, ou seja, aqueles a quem se destinava o Programa, não receberam bolsa do Governo federal para participação nos cursos ofertados pelo Parfor.

A Tabela 1 apresenta os dados de aplicação financeira do Governo Federal no Parfor nacionalmente e por região, no ano de 2009.

Tabela 1 - Aplicação financeira do Parfor para a formação inicial presencial - 2009

\begin{tabular}{rrrrr}
\hline \multicolumn{1}{c}{ Região } & \multicolumn{1}{l}{ Custeio } & \multicolumn{1}{c}{ Capital } & \multicolumn{1}{l}{ Bolsa } & \multicolumn{2}{c}{ Total } \\
\hline CO & 0,00 & 0,00 & 0,00 & 0,00 \\
$\mathrm{~N}$ & $2.406 .863,28$ & 0,00 & $320.400,00$ & $2.727 .263,28$ \\
$\mathrm{NE}$ & $8.757 .058,55$ & 0,00 & $657.900,00$ & $9.414 .958,55$ \\
$\mathrm{~S}$ & $143.370,66$ & 0,00 & $24.600,00$ & $167.970,66$ \\
$\mathrm{SE}$ & $4.948,60$ & 0,00 & $79.200,00$ & $84.148,60$ \\
\hline Totais & $\mathbf{1 1 . 3 1 2 . 2 4 1 , 0 9}$ & $\mathbf{0 , 0 0}$ & $\mathbf{1 . 0 8 2 . 1 0 0 , 0 0}$ & $\mathbf{1 2 . 3 9 4 . 3 4 1 , 0 9}$ \\
\hline
\end{tabular}

Fonte: Coordenação de Aperfeiçoamento de Pessoal de Nível Superior (2012 apud NUCCI, 2013).

Observa-se que o Parfor investiu, em todo o Brasil, mais de R\$ 12 milhões, dos quais mais de R 11 milhões foram gastos com custeio e um milhão foi gasto com pagamento de bolsa. As regiões Norte (N) e Nordeste (NE) obtiveram 97,97\% do total do fomento nacional; somente o Nordeste contou com 75,96\% dos recursos nesse período. A Região Sudeste (SE) apresentou o menor percentual, 0,67\% do total dos recursos, e o Centro-Oeste $(\mathrm{CO})$ não recebeu nenhum fomento nesse período. Ressalta-se que no Centro-Oeste não houve a implantação de turmas especiais no ano de 2009.

A Tabela 2 apresenta os dados do financiamento do Parfor, no país como um todo e por região, no ano de 2010. 
Tabela 2 - Aplicação financeira do Parfor para a formação inicial presencial - 2010

\begin{tabular}{rrrrr}
\hline \multicolumn{1}{c}{ Região } & \multicolumn{1}{c}{ Custeio } & \multicolumn{1}{c}{ Capital } & \multicolumn{1}{c}{ Bolsa } & \multicolumn{1}{c}{ Total } \\
\hline CO & $188.833,37$ & $56.649,44$ & $298.900,00$ & $544.382,81$ \\
N & $14.756 .002,91$ & $384.136,00$ & $14.471 .000,00$ & $29.611 .138,91$ \\
NE & $7.803 .321,49$ & $2.463 .727,50$ & $19.702 .800,00$ & $29.969 .848,99$ \\
S & $1.198 .370,11$ & $294.332,85$ & $881.500,00$ & $2.374 .202,96$ \\
SE & $1.675 .279,91$ & $468.721,22$ & $1.070 .100,00$ & $3.214 .101,13$ \\
\hline Totais & $\mathbf{2 5 . 6 2 1 . 8 0 7 , 7 9}$ & $\mathbf{3 . 6 6 7 . 5 6 7 , 0 1}$ & $\mathbf{3 6 . 4 2 4 . 3 0 0 , 0 0}$ & $\mathbf{6 5 . 7 1 3 . 6 7 4 , 8 0}$ \\
\hline
\end{tabular}

Fonte: Coordenação de Aperfeiçoamento de Pessoal de Nível Superior (2012 apud NUCCI, 2013).

Em 2010, os investimentos apresentaram um crescimento de mais de quatro vezes em relação a 2009 (430,19\%), ultrapassando o valor de R\$ 65 milhões. O custo com o pagamento de bolsas foi de mais de R $\$ 36$ milhões e superou os gastos de custeio e capital, que juntos somaram mais de R \$ 29 milhões.

A Tabela 3 apresenta os dados de financiamento do Parfor em 2011, no Brasil e por região.

Tabela 3 - Aplicação financeira do Parfor para a formação inicial presencial - 2011

\begin{tabular}{rrrrr}
\hline \multicolumn{1}{c}{ Região } & \multicolumn{1}{c}{ Custeio } & \multicolumn{1}{c}{ Capital } & \multicolumn{1}{c}{ Bolsa } & \multicolumn{1}{c}{ Total } \\
\hline CO & $260.193,70$ & 0,00 & $1.015 .300,00$ & $1.275 .493,70$ \\
$\mathrm{~N}$ & $20.191 .877,82$ & $1.353 .111,30$ & $32.924 .500,00$ & $54.469 .489,12$ \\
$\mathrm{NE}$ & $10.742 .758,72$ & $324.263,22$ & $32.227 .800,00$ & $43.294 .821,94$ \\
$\mathrm{~S}$ & $1.943 .482,62$ & $60.613,64$ & $6.470 .600,00$ & $8.474 .696,26$ \\
$\mathrm{SE}$ & $735.479,05$ & $30.471,08$ & $4.272 .000,00$ & $5.037 .950,13$ \\
\hline Totais & $\mathbf{3 3 . 8 7 3 . 7 9 1 , 9 1}$ & $\mathbf{1 . 7 6 8 . 4 5 9 , 2 4}$ & $\mathbf{7 6 . 9 1 0 . 2 0 0 , 0 0}$ & $\mathbf{1 1 2 . 5 5 2 . 4 5 1 , 1 5}$ \\
\hline
\end{tabular}

Fonte: Coordenação de Aperfeiçoamento de Pessoal de Nível Superior (2012 apud NUCCI, 2013).

Nesse período, o financiamento chegou a um total de R\$ 112 milhões. A maior parte dos gastos em 2011 se refere, novamente, ao pagamento de bolsas, que ultrapassou o valor de R $\$ 76$ milhões de reais, superando as despesas com custeio e capital, que totalizaram mais de $\mathrm{R} \$ 35$ milhões.

Os recursos aplicados, portanto, entre 2009 e 2011, totalizaram R\$ 190 milhões. Com o pagamento de bolsas foram gastos mais de R 114 milhões, o maior montante das despesas do programa (60\%). As despesas com custeio somam mais de R $\$ 70$ milhões (37,1\%); e as despesas com capital correspondem a mais de R\$ 5 milhões, 2,9\% do total de recursos aplicados.

Conforme demonstrado, as despesas com pagamento de bolsas apresentaram um percentual de gasto maior do que as despesas com custeio e capital. Isso de- 
monstra que o Governo federal assumiu as despesas referentes à indução da política: implantação e manutenção das turmas, com o pagamento do corpo técnico.

No caso específico de Mato Grosso do Sul, a implementação do Parfor trouxe as marcas estruturais desse modelo, como retrata a direção que a política de formação de professores tem percorrido no Estado. O Parfor foi implantado por meio do Acordo de Cooperação Técnica (ACT) n. 009/2009, celebrado entre a Capes e a Secretaria de Educação de Mato Grosso do Sul (SED/MS), em 28 de maio de 2009, com a validade de sete anos, podendo ser prorrogado por igual período (COORDENAÇÃO DE APERFEIÇOAMENTO DE PESSOAL DE NÍVEL SUPERIOR, 2009). Tem por finalidade conjugar esforços com vistas à implantação do Plano, destinado a atender à demanda de professores das redes estadual e municipal sem formação adequada, como era previsto na Lei de Diretrizes e Bases da Educação Brasileira (Lei n. 9.394/1996).

A Universidade Federal de Mato Grosso do Sul (UFMS), a Universidade Estadual de Mato Grosso do Sul (UEMS), a Universidade Federal da Grande Dourados (UFGD) e o Instituto Federal de Mato Grosso do Sul (IFMS) aderiram à parceria e se comprometeram a ofertar os cursos do Parfor. Os cursos de formação inicial do Parfor em Mato Grosso do Sul foram oferecidos nas modalidades presencial e a distância.

Cabem aqui, antes de se verificar como o Parfor foi implantado em Mato Grosso do Sul, alguns esclarecimentos sobre o mecanismo de funcionamento do Programa. Além de poder oferecer cursos presenciais e a distância, o Parfor pode também oferecer vagas em turmas preexistentes nas instituições de ensino superior parceiras, ou abrir turmas especiais para os professores cursistas. Em ambos os casos, as possibilidades de que isso efetivamente ocorra estão sujeitas à aprovação prévia do órgão gestor, ou seja, da Capes.

Assinale-se ainda que, no que diz respeito ao professor cursista, ${ }^{14}$ o processo envolve três etapas: a pré-inscrição na Plataforma Freire, banco de dados especialmente criado para o Programa; a validação de sua pré-inscrição, ou seja, a pré-inscrição tem que ser validada pelo órgão gestor do Parfor no Estado (no caso em estudo, a SED/MS); e, finalmente, ocorrerá a matrícula no curso e na instituição escolhidos.

Nesse sentido, o Gráfico 2 apresenta o número de vagas ofertadas, de pré-inscrições, de validações e de matrícula nos cursos regulares (existentes) e turmas especiais de formação inicial de primeira e segunda licenciaturas na modalidade presencial, no período de 2009 a 2011. 
Gráfico 2 - Parfor/MS, formação inicial presencial: oferta de vagas, pré-inscrição, validação e matrícula

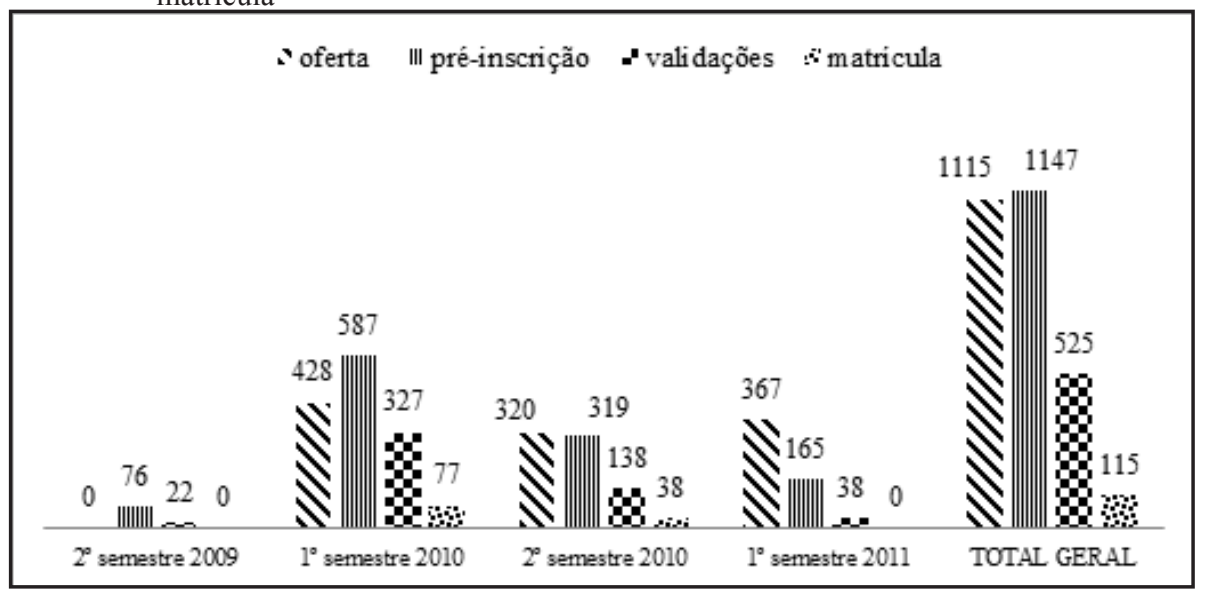

Fonte: Coordenação de Aperfeiçoamento de Pessoal de Nível Superior (2012 apud NUCCI, 2013).

De acordo com os dados apresentados no Gráfico 2, no período de 2009 a 2011, as matrículas corresponderam a um percentual de 10,3\% em relação à oferta, $10 \%$ referentes à pré-inscrição e $21,9 \%$ quanto às validações. Além disso, houve matrícula em dois períodos: primeiro e segundo semestres de 2010. Também

No primeiro semestre de 2010 , o total de matriculados apre-
sentou um percentual de $23,54 \%$ em relação às validações do
período. No segundo semestre de 2010 , as matrículas atingiram
um percentual de $27,53 \%$ em relação às validações ocorridas
no referido semestre. Nos demais períodos (2009 e 2011) não
houve matrícula. (NUCCI, 2013, p. 157).

A relação entre a quantidade de vagas ofertadas e a de pré-inscrições revela que os professores procuraram os cursos do Parfor, mas no momento da validação o número reduziu-se drasticamente. Na matrícula diminuiu mais ainda, atingindo apenas $10,3 \%$ do total da oferta. Os dados demonstram que o percentual de matrícula, nos cursos de formação inicial/presencial, em relação aos pré-inscritos e validados, pode ser considerado baixo.

O Gráfico 3 demonstra a quantidade de matrículas nos cursos de formação inicial por IES em Mato Grosso do Sul, no período de 2009 a 2011. 
Gráfico 3 - Matrícula para a formação inicial por IES, em Mato Grosso do Sul - 2009 a 2011

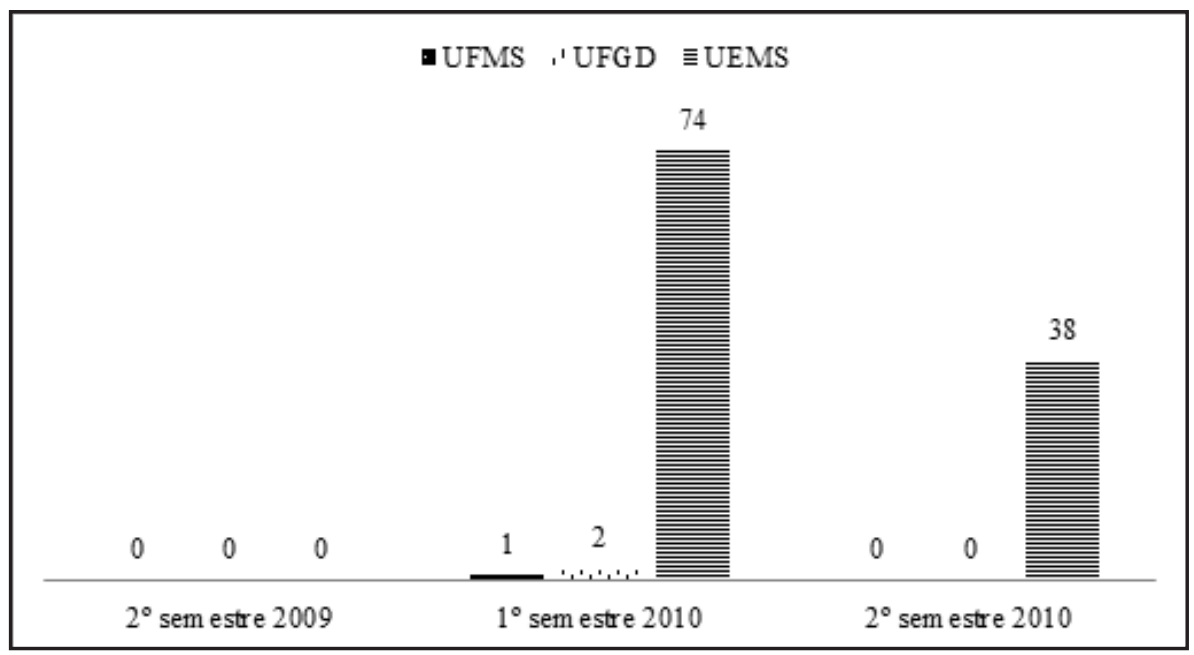

Fonte: Coordenação de Aperfeiçoamento de Pessoal de Nível Superior (2012 apud NUCCI, 2013).

Por meio do Gráfico 3, verifica-se que somente houve matrícula em 2010 e $97,4 \%$ destas se concentraram na UEMS. Consequentemente, apenas ali houve a abertura de turmas especiais. Na UFMS, no período de 2009 a 2010, houve apenas uma matrícula de segunda licenciatura em Educação Física, em curso ali existente. Na UFGD, houve duas matrículas nos cursos existentes de primeira licenciatura, em Matemática e Letras (NUCCI, 2013).

O baixo índice de matrícula aconteceu em virtude da falta de articulação e contrapartida do Governo do Estado de Mato Grosso do Sul, ou seja, este último não estabeleceu uma política para viabilizar as condições necessárias para os professores participarem dos cursos. De acordo com as entrevistas realizadas no decorrer da pesquisa com os dirigentes das IPESs no Estado, a falta de incentivo aos professores cursistas por parte da SED/MS foi o principal motivo para o baixo índice de matrículas em relação à pré-inscrição e às validações.

Eu atribuo essencialmente à falta de condições mesmo, porque esses professores trabalham a grande maioria 40 horas, 44 horas por semana, os cursos mesmo a distância exigem um deslocamento para as avaliações, exige uma série de estrutura que o professor tenha para cursar, e ele trabalhando 44 horas por semana, quer dizer, vai sobrar quanto tempo para ele se dedicar a esse curso? Vai sobrar metade do sábado e o domingo. Pensando que o professor não tem que planejar a aula, que ele também não tem família, então, que hora ele vai poder se dedicar a esse curso? Alguns professores que estão frequentando o curso até hoje, 
[estão] viajando por sua conta, gastando do seu bolso, além de dar 40 horas de aulas por semana, se deslocando às vezes até $300 \mathrm{~km}$ como a gente identificou no caso da UEMS em alguns cursos presenciais, esse professor realmente é aquele que acima de qualquer coisa está buscando a sua formação. Mas não são todos que essas condições, pessoas que têm filhos, por exemplo, família para sustentar, é evidente que essa pessoa também não fez um curso superior até hoje porque não tem essas condições, porque se tivesse já teria feito em uma instituição privada, em uma instituição que ele não precise viajar para fazer, enfim, ele não fez porque ele não tem essas condições. Então eu vejo que o Parfor tem esse grande comprometimento se os Estados e municípios não se envolverem com essa parte do apoio ao professor, um ônibus que possa levar esses professores até o local de formação e dispensa em um determinado horário para que ele possa cursar o curso, que seja 10 horas por semana, vamos dizer para simplificar a coisa, que não seja uma dispensa integral [mas] que seja parcial, com o salário, sem prejuízo de salário, mas isso a gente não observa em nenhuma instância aqui no Mato Grosso de Sul. (Informação verbal da Entrevista 3 apud NUCCI, 2013, p. 159).

A falta de apoio da SED/MS - no que se refere à dispensa dos professores e ao provimento de recursos para o custeio de despesas referentes à participação dos docentes nos cursos presenciais - desmotivou-os a procurarem os cursos oferecidos pelo Parfor. Ressalta-se que, por esse motivo, os cursos oferecidos pela UEMS foram realizados nos finais de semana e feriados. Assim, o Estado, colocando-se favorável ao pressuposto da perspectiva neoliberal, delegou aos professores (campo privado) a responsabilidade pela melhoria de sua formação profissional.

O Gráfico 4 apresenta os dados quantitativos da oferta, da pré-inscrição dos professores e da matrícula nos cursos de formação inicial na modalidade a distância no período de 2009 a 2011. 
Gráfico 4 - Formação inicial a distância: oferta de vagas, pré-inscrição e matrícula em Mato Grosso do Sul - 2009 a 2011

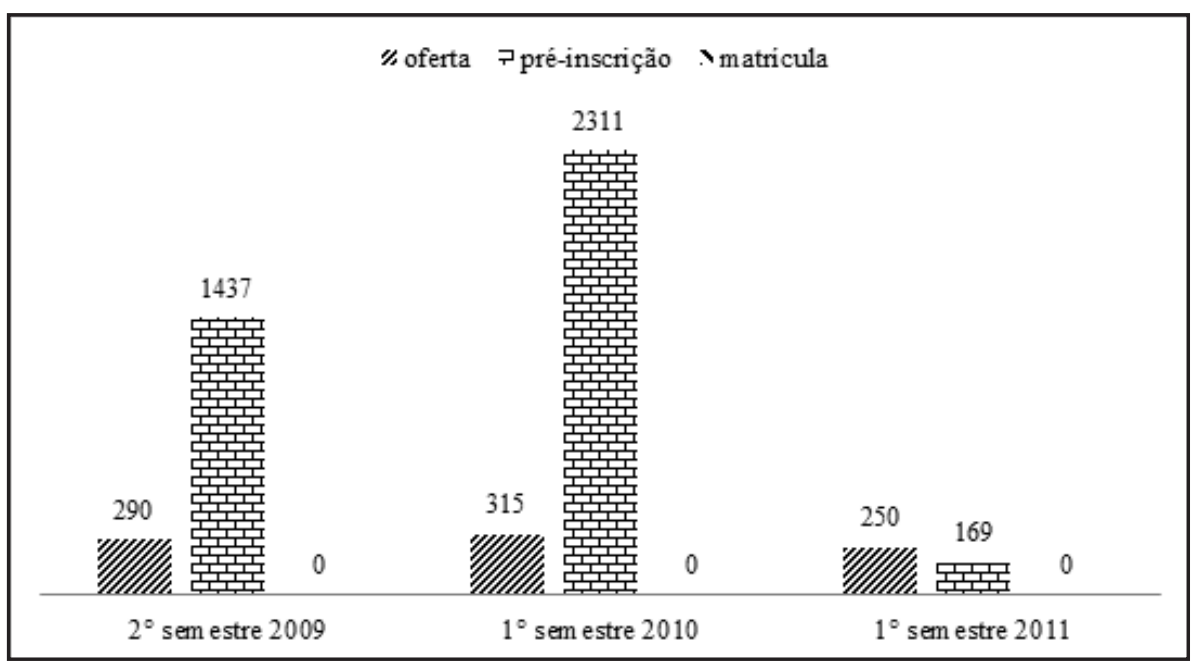

Fonte: Coordenação de Aperfeiçoamento de Pessoal de Nível Superior (2012a).

Ressalta-se que em 2009 os cursos do Parfor foram oferecidos somente na modalidade a distância (EAD), e que nos demais anos a procura dos professores por essa modalidade superou a presencial. Apesar dessa condição, não houve matrícula.

No primeiro semestre de 2010, a procura por cursos de formação inicial na modalidade a distância novamente excedeu em quase quatro vezes a procura pela modalidade presencial. Pode-se dizer que a falta de incentivo para a participação nos cursos presenciais fez com que os professores preferissem os cursos na modalidade a distância. No que se refere à matrícula, contudo, observa-se que mesmo com um número elevado de procura (pré-inscrição) dos professores, as matrículas não se concretizaram.

Outro aspecto relevante para se entender a implantação da EAD foi que a SED/MS não se comprometeu financeiramente com a abertura de novos polos de educação a distância para a execução dos cursos. A fala da dirigente 3 mostra o ocorrido:

[...] porque a Secretaria seria a responsável por criar esses polos, e a Secretária não entendeu dessa forma, ela entendia que quem tinha que dar as condições para o polo funcionar era a Universidade. Aliás, me parece que ele entendia que a universidade seria o polo, e aí foi muito difícil essa negociação até convencer a Secretária de que o polo é outra coisa. Inclusive porque se a Universidade assume a função de polo toda a obrigação do Estado acaba se diluindo, porque o Estado que teria que viabilizar condições, funcionários, e aí a Universidade assumiria tudo. Então nós tivemos que definir com a Secretária as responsabilidades da Universidade claramente pelo projeto pedagógico, professo- 
res, acompanhamento desse curso de formação e da Secretaria de disponibilizar o polo. Então aí, do período que eu conversei, inclusive, eu fui aqui em Dourados verificar o local que poderia ser o polo, retornei para a professora Nilene (Secretária de Estado de Educação de Mato Grosso do Sul), negociamos várias vezes, mas nada foi feito para a implantação desse polo. (Informação verbal da Entrevista 3 apud NUCCI, 2013, p. 156).

Fica evidente, que no momento de viabilizar a execução dos cursos, o Governo do Estado eximiu-se de sua responsabilidade, e acabou por impossibilitar a implantação dos cursos a distância. Por fim, frustrou os professores pré-inscritos e validados para a realização da matrícula e gerou um descrédito nos cursistas em relação ao Programa.

Como resultado desse processo, o Parfor não se concretizou como planejado, embora a pré-inscrição dos professores no primeiro semestre de 2009 e 2010 tenha se mostrado expressiva. Como afirmado anteriormente, o percentual de matrícula foi baixo em relação às pré-inscrições e validações e isso ocorreu em razão da falta de condições de participação dos professores. De fato, os professores não foram dispensados para participar dos cursos e não receberam ajuda financeira para custear suas despesas.

Procurando caracterizar melhor a implementação do Programa em Mato Grosso do Sul, apresentam-se os cursos do Parfor oferecidos na UEMS, a IPES que mais ofertou vagas entre 2009 e 2011. O Gráfico 5 apresenta o quantitativo geral de oferta, pré-inscrições, validações e matrículas nos cursos de formação inicial na modalidade presencial oferecidos pela UEMS, no período de 2010 a 2011.

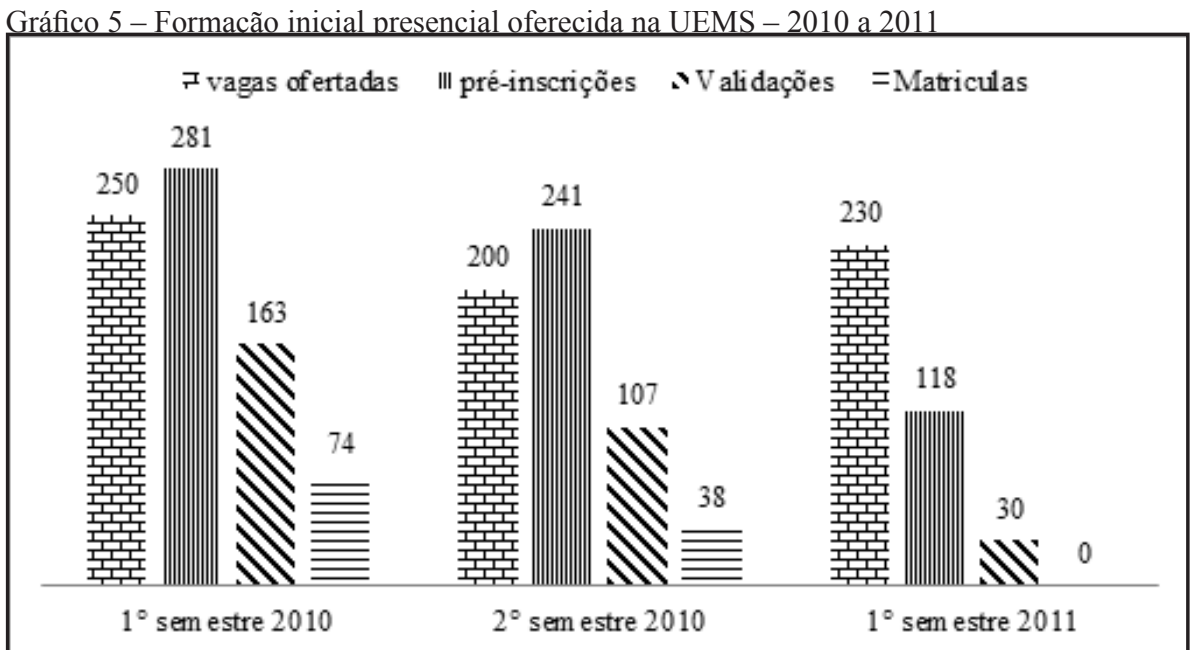

Fonte: Coordenação de Aperfeiçoamento de Pessoal de Nível Superior (2012 apud NUCCI, 2013). 
No Gráfico 5, verifica-se que somente no ano de 2010 houve matrículas nos cursos do Parfor na UEMS. No primeiro semestre de 2010, a matrícula apresentou um percentual de 45,39\% em relação às validações; no segundo, 35,51\%. Em 2011 não houve matrícula. Segundo Nucci (2013), o baixo percentual de matrículas em relação às inscrições validadas pela SED/MS foi atribuído à inexistência de incentivo e apoio do Estado aos professores cursistas, conforme fala da dirigente 2, a seguir citada. Assim, a falta de articulação e contrapartida do Governo do Estado de Mato Grosso do Sul, que não estabeleceu uma política para viabilizar as condições necessárias para os professores participarem dos cursos do Parfor, explica a dificuldade dos cursistas em aderirem a estes:

[...] o que a gente percebe é isso, que a demanda não se concretiza e das turmas que a gente conseguiu efetivar, a gente tem algumas reclamações por parte dos alunos, principalmente na questão da falta de apoio por parte das Secretarias de Educação, no sentido de dar condições melhores para que eles possam frequentar o curso, tanto o sentido de liberar eles das atividades da escola pelo menos uma vez por semana, que é só sexta-feira, porque nossos cursos são trabalhados sexta, sábado, recessos e feriados, já para tentar não atrapalhar muito a vida do professor, mas mesmo assim eles têm essa dificuldade, muitos deles nos relataram que eles têm que pagar alguém para poder frequentar o curso, tem muitos professores que não residem no município onde a gente oferta o curso, então eles têm que se deslocar e eles também não tem nenhum apoio por parte das secretarias, enfim, isso dificulta bastante. A gente acabou tendo em algumas turmas um índice de evasão um pouquinho grande, até por conta dessa dificuldade às vezes dos alunos [...] (Informação verbal da Entrevista 2, 2012 apud NUCCI, 2013, p. 161-162).

Apesar dos entraves, no primeiro semestre de 2010, a UEMS ofertou vagas em cinco cidades (Campo Grande, Cassilândia, Dourados, Jardim e Nova Andradina) e em seis cursos diferentes (Geografia, Língua Inglesa, Física, Química, Educação Física e Informática). Foram ofertadas 250 vagas no total - das quais 50 vagas em cursos regulares e 200 em cursos especiais de primeira e segunda licenciaturas.

Considerando somente os cursos especiais, a UEMS teve 204 inscrições, 118 validações e 68 matrículas. Foram abertas três turmas especiais: duas em Dourados - segunda licenciatura em Física, com 19 matriculados, e segunda licenciatura em Química, com 16 matriculados - e uma em Jardim - primeira licenciatura em Educação Física, com 33 matriculados.

Os cursos de Química e Física oferecidos em Dourados no primeiro semestre de 2010 receberam aprovação ad hoc da Capes. Por quê? De fato, os cursos foram ofe- 
recidos, os professores realizaram a pré-inscrição na Plataforma Freire e as validações foram realizadas pela SED/MS. No momento da matrícula dos professores, no entanto, a UEMS constatou que alguns professores não correspondiam aos critérios do Plano e resultou que o número de professores não seria suficiente para a abertura das turmas. A Capes entrou, então, em contato com a UEMS, que solicitou e obteve autorização para a abertura das turmas com um número de inscritos menor do que o recomendado.

É importante frisar que a validação dos professores que se pré-inscrevem na Plataforma Freire, como afirmado anteriormente, é de responsabilidade do gestor estadual. A SED/MS apresentou falhas na realização dessa etapa, pois alguns professores validados não correspondiam aos critérios adotados no Parfor. Isso explica, em parte, a queda no número de matrículas em relação às validações.

No segundo semestre de 2010, foram oferecidas 200 vagas nos cursos de segunda licenciatura, turmas especiais, em quatro cidades: Campo Grande (Letras), Dourados (Espanhol), Jardim (Espanhol) e Nova Andradina (Informática). Somente o curso de Informática na cidade de Nova Andradina registrou matrícula e a abertura de uma turma especial, com 38 professores cursistas. Nos demais cursos não houve matrícula, portanto, também não houve abertura de turmas.

No início de 2011, visando minorar o problema relativo às baixas inscrições e matrículas, a quantidade mínima de inscritos para a abertura de turmas foi reduzida para 15 nos cursos de Química, Física, Matemática, Biologia, Música e Informática. ${ }^{15}$ Para a abertura de turmas especiais nas demais disciplinas, foram exigidos somente 25 alunos inscritos.

Apesar disso, e embora a UEMS tenha continuado a ofertar as vagas, nenhum dos cursos ofertados conseguiu atingir o número mínimo exigido pelo Programa, portanto, não houve abertura de novas turmas.

Cabe questionar o porquê dessa situação, visto que a Capes flexibilizou a exigência mínima de matrículas para algumas áreas. Ora, os cursos presenciais exigem que o professor se disponha a frequentá-los fora do horário de aula, desloque-se e ainda pague todas as despesas advindas. A falta de incentivo do Governo do Estado para viabilizar a participação dos professores nos cursos do Parfor tem se tornado um entrave no recrutamento de professores para a abertura de turmas especiais. ${ }^{16}$

Também no que se refere à organização do Plano Estadual de Formação Docente em Mato Grosso do Sul, pode-se destacar que a SED/MS não cumpriu seu papel de condução do Fórum Estadual Permanente de Apoio à Formação Docente/ MS. ${ }^{17}$ A omissão da SED/MS nesse colegiado também prejudicou as articulações necessárias para traçar as estratégias de ação e sobrecarregou as IPESs que, sozinhas, não conseguiram articular e conduzir o seu desenvolvimento e ampliação. 
Assim, com base em dados obtidos por meio de entrevista, pode-se dizer que o Fórum Estadual Permanente de Apoio à Formação Docente em Mato Grosso do Sul, criado pelo Decreto n. 4.106, de 21 de outubro de 2009 (MATO GROSSO DO SUL, 2009), com o intuito de elaborar os planos estratégicos, articular ações e acompanhar o andamento do Parfor, não cumpriu o calendário de reuniões estabelecidas. ${ }^{18}$ Ele existe formalmente, destaca a Dirigente 2, contudo:

[...] a avaliação que eu faço do nosso Fórum é bem negativo [...] Porque há um ano a gente não consegue fazer isso [reunião] quer dizer, as duas últimas ofertas que a gente fez, o Fórum não participou, a gente fez uma previsão de oferta interna, foi aprovada aqui pela instituição, foi encaminhada para o Fórum, mas aí o Fórum não fez a parte dele, ele nem nos chamou para definir ou discutir aquilo ali, muito menos encaminhou a oferta para a Capes, isso aconteceu ano passado e voltou a se repetir esse ano [...] (Informação verbal da Entrevista 2 apud NUCCI, 2013, p. 145).

Assim, constata-se que a Secretaria de Educação somente se limitou a assinar o compromisso de instalação do Parfor em Mato Grosso do Sul. Como não foram especificadas as obrigações do Estado para garantir a oferta, o órgão acabou transferindo o encargo da formação para os próprios professores e responsabilizando os sujeitos pela sua qualificação profissional, seguindo a clássica agenda neoliberal.

\section{CONSIDERAÇÕES FINAIS}

No contexto das mudanças provocadas pela rearticulação do capitalismo no âmbito mundial, iniciada nos anos 1970, houve transformações desde suas bases produtivas, chegando ao Estado e, consequentemente, nas políticas sociais e, em particular, nas educacionais.

No caso do Brasil essas reformas se fizeram presentes a partir dos anos 1980, nos setores produtivos, e nos anos 1990, com a reforma do Estado, baseada na ideologia neoliberal. Nesse sentido, há um movimento de reconfiguração do papel do Estado, que passou a desempenhar, no campo social, a função de articulador e de organizador de políticas sociais, inclusive descentralizando as funções de gestão e operacionalização. Para tal, o ajuste neoliberal provocou o corte no orçamento das políticas sociais, que passaram a ter um novo rosto, ou seja, um caráter focal e emergencial.

Em relação ao campo educacional, o professor e sua formação eram elementos considerados pelo Estado como pivôs da crise na área, o que se tornou uma justificativa para focalizar uma parte das iniciativas reformistas em sua formação. 
Nesse sentido, desde as gestões de FHC e posteriormente, nos governos Lula da Silva e Dilma Rousseff, programas emergenciais foram dirigidos para a solução desse impasse, em um país onde era significativo o número de professores atuando na rede pública de educação básica, sem a formação adequada. O Parfor, que funciona desde 2009, faz parte das políticas educacionais desenvolvidas no período dos governos de Luiz Inácio Lula da Silva e Dilma Rousseff para o campo da educação, com vistas a diminuir as desigualdades e as falências na formação de professores.

No período de 2009 a 2011, aderiram ao Parfor 142 IESs, destas 75 abriram cursos distribuídos em 1.421 turmas em 52 cursos de licenciatura (COORDENAÇÃO DE APERFEIÇOAMENTO DE PESSOAL DE NÍVEL SUPERIOR, 2011b). O quantitativo de professores formadores atingiu o número de 23.877 e o financiamento do Parfor chegou a R\$ 190 milhões, dos quais R\$ 114 milhões foram gastos com o pagamento de bolsas para os professores das instituições formadoras, um dos compromissos da União com o Programa.

No caso de Mato Grosso do Sul, que foi examinado neste artigo, em razão dos mecanismos de implementação do Programa, que previa a colaboração dos Entes Federativos, a implementação do Parfor não obteve o êxito esperado. A falta de incentivo à participação dos professores cursistas foi um dos principais motivos do baixo número de matrículas. Conforme observado, o Governo do Estado negligenciou sua função de articular e financiar as despesas oriundas da participação dos professores. Assim, um elemento importante que comprometeu a execução do Parfor em Mato Grosso do Sul foi a falta de articulação e compromisso da SED/MS.

Ressalta-se também que, uma vez que os professores cursistas em Mato Grosso do Sul não tiveram acesso a bolsas ou dispensa para frequentar as aulas, a participação deles no Parfor exigia disponibilidade de tempo além da carga horária em sala de aula, mais propriamente nos finais de semana e feriados, períodos em que os cursos foram ministrados na UEMS. Além disso, os docentes tinham que assumir as despesas referentes ao deslocamento até o polo mais próximo, hospedagem e alimentação.

Esses obstáculos, oriundos da forma como o Governo do Estado deixou de proporcionar as condições necessárias para a viabilização do Plano - acordante com as propostas neoliberais - transferiram para os próprios professores a responsabilidade e a possibilidade de participação nos cursos do Parfor. Isso se tornou, certamente, um dos fatores determinantes para o resultado pífio da primeira etapa (2010 e 2011) de implantação dessa política de formação de professores em Mato Grosso do Sul. 
${ }^{1}$ Este artigo compõe a produção relacionada ao projeto de pesquisa intitulado A política educacional no contexto das relações federativas no Brasil, financiado pelo CNPq, e coordenado pela Profa. Dra. Margarita Victoria Rodríguez/UFMS.

${ }^{2}$ Embora estivesse em vigor o Plano Nacional de Educação, o Governo Lula da Silva, visando delimitar um espaço diferenciado para suas diretrizes no campo educacional, lançou em abril de 2007 o Plano de Desenvolvimento da Educação (PDE) “[...] como um programa articulado para a educação, com estratégias e um conjunto de atos normativos. [...] O interlocutor privilegiado no processo foi o grupo Compromisso Todos pela Educação, constituído por empresários e representantes de fundações empresariais (Fundação Ayrton Senna, Grupo Pão de Açúcar, Fundação Bradesco, Instituto Gerdau, Fundação Roberto Marinho etc.), que trouxeram para o campo educacional uma concepção de gestão gerencial. Simultaneamente ao lançamento do PDE, foi publicado o Decreto $n^{\circ}$ 6.094, de 24 de abril de 2007, que dispôs sobre a implementação do Plano de Metas Compromisso Todos pela Educação, alicerce do Plano de Desenvolvimento da Educação, tendo como objetivo conjugar esforços da União, dos estados, do Distrito Federal, dos municípios e da comunidade para assegurar a qualidade da educação básica.” (SCHIMONEK, 2014, p. 8-9).

${ }^{3}$ Primeira licenciatura - ofertada para docentes em exercício na rede pública da educação básica que não tenham formação superior; Segunda licenciatura - ofertada para docentes em exercício há pelo menos três anos na rede pública da educação básica, e que atuem em área diferente da sua formação inicial; Formação pedagógica - ofertada para docentes graduados não licenciados, que se encontram em exercício na rede pública da educação básica (CAPES, 2011a).

${ }^{4}$ Sobre a origem do Plano de Metas Compromisso Todos pela Educação cf. nota 1.

${ }^{5}$ Conforme Lukács, "não é o predomínio de motivos econômicos na explicação da história que distingue de maneira decisiva o marxismo da ciência burguesa, mas o ponto de vista da totalidade. A categoria da totalidade, o domínio universal e determinante do todo sobre as partes, constitui a essência do método que Marx recebeu de Hegel e transformou de maneira original no fundamento de uma ciência inteiramente nova." (LUKÁCS apud MÉZSÁROS, 2013, p. 57). Ou ainda, como acrescenta Lukács, a totalidade diz respeito a um complexo de variados complexos, conectados dialeticamente, de forma contraditória.

6 "O Estado vinha de um período de intervencionismo ativo na economia (Keynesianismo), através do estímulo ao investimento estatal direto, incentivo ao crescimento dos mercados de consumo, juntamente ao auxílio decisivo dado à reprodução da força de trabalho, com as políticas sociais de pretenso caráter distributivistas." (PANIAGO, 2013, p. 69).

${ }^{7}$ De acordo com Sandroni (1999), ficou conhecido como Consenso de Washington um conjunto de trabalhos e documentos resultantes de encontros realizados na referida cidade, no início dos anos 1990, reunindo instituições como o Fundo Monetário Internacional (FMI), o Banco Internacional para Reconstrução e Desenvolvimento (BIRD), organismo relacionado ao Banco Mundial, e o Tesouro dos Estados Unidos. Assim, "Destas reuniões surgiram recomendações dos países desenvolvidos para que os demais, especialmente aqueles em desenvolvimento, adotassem políticas de abertura de seus mercados e o (Estado Mínimo), isto é, um Estado com um mínimo de atribuições (privatizando as atividades produtivas) e, portanto com o mínimo de despesas como forma de solucionar os problemas relacionados com a crise fiscal; [...] Além disso, o livre funcionamento dos mercados, com eliminação de regulações e intervenções governamentais, também tem sido uma das molas-mestras dessas recomendações. Embora os países que seguiram tal receituário tenham sido bem-sucedidos no combate à inflação, no plano social as consequências foram desalentadoras: um misto de desemprego, recessão e baixos salários, conjugado com um crescimento econômico insuficiente revela a outra face dessa moeda." (SANDRONI, 1999, p. 123).

${ }^{8}$ Lima e Martins (2005, p. 43, grifo nosso) lembram que, "Em uma leitura mais crítica, [...] [a Terceira Via] pode ser também [...] [nomeada] de 'social-liberalismo', conceituação que mais claramente expressa a retomada 'envernizada' do projeto burguês que mantém as premissas básicas do neoliberalismo em associação aos elementos centrais do reformismo social-democrata."

${ }^{9}$ Não é objetivo deste trabalho discutir a questão do desenvolvimento, tal como vem sendo formulado na perspectiva do chamado novo-desenvolvimentismo. Registre-se, no entanto, a perspectiva defendida pelo economista Ricardo Bielschowsky (2013, p. 37), afirmando que "O ponto central aqui apresentado é o de que o Brasil tem o privilégio de possuir, ao mesmo tempo, três poderosas frentes de expansão, três 'motores' do desenvolvimento, um conjunto que poucos países do mundo possuem: • um amplo mercado interno de 
consumo de massa - que será tanto mais amplo quanto melhor vier a ser a distribuição da renda - e também uma estrutura produtiva potencialmente capaz de vir a realizar localmente boa parte da produção em larga escala correspondente, nos setores primários, industriais e de serviços, sem prejuízo de ampliar as exportações; • uma forte demanda nacional e mundial por seus abundantes recursos naturais; $\mathrm{e} \cdot$ perspectivas favoráveis quanto à demanda estatal e privada por investimentos em infraestrutura (econômica e social). Se os impulsos à expansão da capacidade produtiva derivados dessas três correntes de demanda efetiva vierem a ser adequadamente traduzidos em expansão do investimento no país, o desenvolvimento brasileiro poderá ser vigoroso nas próximas décadas." Com base em tais premissas, principalmente, considerando o papel indutor que teria a escolarização na direção de melhorar o quadro da distribuição de renda no país e, complementarmente, a necessária ação estatal nessa direção, que vem sendo reafirmada a relação entre educação e desenvolvimento.

${ }^{10}$ Ressalta-se que os avanços relacionados com a questão da formação dos professores também estiveram associados à luta e intensa participação do movimento docente em defesa da valorização do magistério e em prol da elaboração de uma proposta de formação inicial dos professores com base na docência. Nesse sentido, contou-se com a contribuição da Comissão de Especialistas de Ensino de Pedagogia, cujos trabalhos culminaram com a aprovação das Diretrizes Curriculares para o Curso de Pedagogia, em 1999 (BRASIL, 1999). Posteriormente a ANPED, ANFOPE, ANPAE, FORUMDIR e Fórum Nacional em Defesa da Formação do Professor apresentam um documento conjunto na Reunião de Consulta com o Setor Acadêmico, no âmbito do Programa Especial "Mobilização Nacional por uma Nova Educação Básica" (CNE, 2001), onde manifestavam o seu descontentamento e preocupação a respeito da possível extinção do Curso de Pedagogia nesse momento histórico, uma vez que o governo FHC vinha se mostrando favorável à criação dos cursos normais superiores (FREITAS, 2002).

${ }^{11}$ a) Alfabetização e Linguagem: Universidade Federal de Pernambuco (UFPE); Universidade Federal de Minas Gerais (UFMG); Universidade Estadual de Ponta Grossa (UEPG); Universidade de Brasília (UnB); Universidade Estadual de Campinas (Unicamp). b) Educação Matemática e Científica: Universidade Federal do Pará (UFPA); Universidade Federal do Rio de Janeiro (UFRJ); Universidade Federal do Espírito Santo (UFES); Universidade Estadual Paulista (Unesp); Universidade do Vale do Rio dos Sinos (Unisinos); c) Ensino de Ciências Humanas e Sociais: Universidade Federal do Amazonas (UFAM); Universidade Federal do Ceará (UFC); Pontifícia Universidade Católica de Minas Gerais (PUC-MG). d) Artes e Educação Física: Universidade Federal do Rio Grande do Norte (UFRN); Pontifícia Universidade Católica de São Paulo (PUC-SP); Universidade Federal do Rio Grande do Sul (UFRGS). e) Gestão e Avaliação da Educação: Universidade Federal da Bahia (UFBA); Universidade Federal de Juiz de Fora (UFJF); Universidade Federal do Paraná (UFPR) (BRASIL, 2006).

${ }^{12}$ Com essa observação, deve ser observado também que a questão das diferenças regionais está sujeita a múltiplas determinações, como as dimensões diferenciadas, histórica e socialmente falando, das redes de ensino em cada região; as formas como se materializam as relações federativas no país, entre outros.

${ }^{13}$ A título de exemplo, no ano de 2011 foi oferecido um total de 23.877 bolsas relativas aos cursos presenciais do Parfor (COORDENAÇÃO DE APERFEIÇOAMENTO DE PESSOAL DE NÍVEL SUPERIOR), 2011b, p. 193). Essa tem sido, portanto, a estratégia que o Governo federal tem adotado para atender à demanda da formação de professores no âmbito do Parfor. Como foge aos objetivos deste trabalho, a discussão acerca do que isso pode acarretar para os docentes das instituições formadoras, em especial em decorrência da intensificação do trabalho docente, sugere-se a consulta aos trabalhos de Bosi (2007) e Borsoi e Pereira (2013). ${ }^{14}$ Considerando-se que o Parfor está destinado à formação de docentes em exercício na rede pública de ensino, optou-se por manter-se a denominação professores para os cursistas, mesmo que estejam na situação de docentes em formação.

${ }^{15}$ Para tal, deve ter sido considerado o fato de que essas são áreas tradicionalmente marcadas pela falta crônica de docentes habilitados, nas redes de educação básica.

${ }^{16}$ Vale lembrar que no Acordo de Cooperação Técnica celebrado entre a Capes e o Estado de Mato Grosso do Sul não deixa claro o papel dos Entes Federados no que se refere à execução do Parfor, imprecisão esta que acabou por fortalecer o papel secundário exercido pela Secretaria de Educação estadual e enfraqueceu o regime de colaboração. Apenas em 2011, a Capes, logo após assumir definitivamente o Parfor, apresentou um documento diretriz no qual esclarece e define o papel de cada Ente na implementação do Parfor.

${ }^{17}$ Os Fóruns Estaduais Permanentes de Apoio à Formação Docente são órgãos colegiados criados para atribuir cumprimento aos objetivos da Política Nacional de Formação de Profissionais do Magistério da 
Educação Básica, instituída pelo Ministério da Educação (MEC), por meio do Decreto n. 6.755, de 29 de janeiro de 2009 (BRASIL, 2009a).

${ }^{18}$ Considerando os limites deste trabalho, não será possível a análise pormenorizada da ação dos Fóruns. Confira a respeito em Brzezinski (2014).

\section{REFERÊNCIAS}

ABREU, H. B. de. As novas configurações do Estado e da sociedade civil. In: CAPACITAÇÃO EM SERVIÇO SOCIAL E POLÍTICA SOCIAL: Módulo 1. Brasília, DF: CEAD, 1999.

BIELSCHOWSKY, R. Estratégia de desenvolvimento e as três frentes de expansão no Brasil: um desenho conceitual. In: FUNDAÇÃO PERSEU ABRAMO. Desenvolvimento. São Paulo: FPA, 2013.

BORSOI, I. C. F.; PEREIRA, F. S. Professores do ensino público superior: produtividade, produtivismo e adoecimento. Univ. Psychol., Bogotá, v. 12, n. 4, p. 12131225, dez. 2013. Disponível em: <http://www.scielo.org.co/scielo.php?script=sci arttext\&pid=S1657-92672013000400018\&lng=en\&nrm=iso $>$. Acesso em: 15 out. 2014.

BOSI, A. de P. A precarização do trabalho docente nas instituições de ensino superior do Brasil nesses últimos 25 anos. Educ. Soc., Campinas, v. 28, n. 101, p. 1503-1523, dez. 2007. Disponível em: <http://www.scielo.br/scielo.php?script=sci arttext\&pid=S0101-73302007000400012\&lng=en\&nrm=iso $>$. Acesso em: 28 set. 2014.

BRZEZINSKI, I. Sujeitos sociais coletivos e a política de formação inicial e continuada emergencial de professores: contradições vs conciliações. Educ. Soc., Campinas, v. 35, n. 129, p. 1241-1259, dez. 2014. Disponível em: <http://www.scielo.br/ scielo.php?script=sci_arttext\&pid=S0101-73302014000401241\&lng=en\&nrm=iso $>$. Acesso em: 11 abr. 2014.

BRASIL. Decreto n. 5.800, de 08 de junho de 2006. Dispõe sobre o Sistema Universidade Aberta do Brasil - UAB. Brasília, DF, Diário Oficial da União, 09 jun. 2006.

BRASIL. Decreto n. 6.094, de 24 de abril de 2007. Dispõe sobre a implementação do Plano de Metas Compromisso Todos pela Educação, pela União Federal, em regime de colaboração com os municípios, Distrito Federal e estados, e a participação das famílias e da comunidade, mediante programas e ações de assistência técnica e financeira, visando mobilização social pela melhoria da educação básica. Diário Oficial da União, Brasília, DF, 25 abr. 2007. Disponível em: <http://www.planalto. gov.br/ccivil_03/_ato2007-2010/2007/decreto/d6094.htm>. Acesso em 03 abr. 2014. 
BRASIL. Decreto n. 6.755, de 29 de janeiro de 2009. Institui a Política Nacional de Formação de Profissionais do Magistério da Educação Básica, disciplina a atuação da Coordenação de Aperfeiçoamento de Pessoal de Nível Superior - CAPES no fomento a programas de formação inicial e continuada, e dá outras providências. Diário Oficial da União, Brasília, DF, 30 jan. 2009a. Disponível em: <http://www.planalto.gov.br/ ccivil_03/ato2007-2010/2009/decreto/d6755.htm>. Acesso em: 20 jun. 2011.

BRASIL. Lei n. 11.502, de 11 de julho de 2007. Modifica as competências e a estrutura organizacional da fundação Coordenação de Aperfeiçoamento de pessoal de Nível Superior - CAPES, de que trata a Lei n. 8.405, de 09 de janeiro de 1992; e altera as Leis n. 8.405, de 09 de janeiro de 1992, e 11.273, de 06 de fevereiro de 2006, que autoriza a concessão de bolsas de estudo e de pesquisa a participantes de programas de formação inicial e continuada de professores para a educação básica. Brasília, DF, Diário Oficial da União, 12 jul. 2007 b.

BRASIL. Ministério da Educação. Portaria Normativa n. 9, de 30 de junho de 2009. Institui o Plano Nacional de Formação dos Professores da Educação Básica no âmbito do Ministério da Educação. Diário Oficial da União, n. 123, Seção 1, Brasília, 01 jul. 2009b. Disponível em: <http://portal.mec.gov.br/dmdocuments/port_normt_09_300609.pdf>. Acesso em: 04 abr. 2011.

BRASIL. Ministério da Educação. Secretaria da Educação Básica. Rede Nacional de Formação Continuada de Professores da Educação Básica: orientações gerais. Brasília, DF, MEC, 2005.

CASTRO, J. A. de et al. Gasto Social Federal: prioridade macroeconômica no período 1995-2010. Brasília, IPEA, 2012. (Nota técnica, 9). Disponível em: <http:// www.ieprev.com.br/userfiles/file/Sumulas/IPEA\%20\%20120904_notatecnicadisoc09.pdf>. Acesso em: 14 fev. 2014.

CONSED. Diretrizes para subsidiar a formulação de um Programa de Titulação dos Docentes do Ensino Fundamental. Documento para discussão. Brasília, DF, 1998. Mimeo.

COORDENAÇÃO DE APERFEIÇOAMENTO DE PESSOAL DE NÍVEL SUPERIOR (CAPES/MEC). Acordo de Cooperação Técnica n. 009/2009. Diário Oficial da União, Brasília, DF, n. 141, seção 3, p. 35-36, 27 jul. 2009. Disponível em: $<$ http://pesquisa.in.gov.br/imprensa/jsp/visualiza/index.jsp?jornal=3\&pagina $=35 \&$ da $\mathrm{ta}=27 / 07 / 2009>$. Acesso em: 20 jul. 2014.

COORDENAÇÃO DE APERFEIÇOAMENTO DE PESSOAL DE NÍVEL SUPERIOR (CAPES/MEC). Dados estatísticos (PARFOR). Brasília, DF: Diretoria de Educação Básica Presencial, 2012a. 
COORDENAÇÃO DE APERFEIÇOAMENTO DE PESSOAL DE NÍVEL SUPERIOR [CAPES/MEC]. Dados estatísticos do PARFOR 2014. Brasília, DF: Diretoria de Educação Básica Presencial, 2014.

COORDENAÇÃO DE APERFEIÇOAMENTO DE PESSOAL DE NÍVEL SUPERIOR (CAPES/MEC). Ofício Circular n. 011/2011-CGDOC/DEB: Plano Nacional de Formação de Professores da Educação Básica Modalidade Presencial - Orientações Gerais. Brasília, DF: Diretoria de Educação Básica Presencial, 2011a.

COORDENAÇÃO DE APERFEIÇOAMENTO DE PESSOAL DE NÍVEL SUPERIOR (CAPES). Plataforma Freire - previsão de ofertas. 2012b. Disponível em: $<$ http://freire.mec.gov.br/index-static $>$. Acesso em: 20 fev. 2012.

COORDENAÇÃO DE APERFEIÇOAMENTO DE PESSOAL DE NÍVEL SUPERIOR (CAPES/MEC). Relatório de Gestão do exercício de 2011. Brasília, DF: 2011b. Disponível em: <https://www.capes.gov.br/images/stories/download/bolsas/ relatorio_gestao_2011.pdf>. Acesso em: 20 abr. 2014.

FREITAS, H. C. L. de. A (nova) política de formação de professores: a prioridade postergada. Educ. Soc., Campinas, v. 28, n. 100, out. 2007. Disponível em: $<$ http:// www.scielo.br/scielo.php?script=sci_arttext\&pid=S0101-73302007000300026\&lng $=$ en\&nrm $=$ iso $>$. Acesso em: 20 maio 2014.

FREITAS, H. C. L. de. Formação de professores no Brasil: 10 anos de embate entre projetos de formação. Educ. Soc., Campinas, v. 23, n. 80, p. 136-167, set. 2002. Disponível em: $<$ http://www.scielo.br/scielo.php?script=sci_arttext\&pid=S0101$-73302002008000009 \& \operatorname{lng}=$ en\&nrm=iso >. Acesso em: 11 abr. 2014.

FRIGOTTO, G. Os circuitos da história e o balanço da educação no Brasil na primeira década do século XXI. Revista Brasileira de Educação, v. 16, n. 46, p. 235-274, 2011.

INSTITUTO NACIONAL DE ESTUDOS E PESQUISAS EDUCACIONAIS ANÍSIO TEIXEIRA. Sinopse estatística da educação básica. Brasília, DF: 2013. Disponível em: <http://portal.inep.gov.br/basica-censo-escolar-sinopse-sinopse>. Acesso em: 30 abr. 2014.

MATO GROSSO DO SUL (Estado). Decreto n. 4.106, de 21 de outubro de 2009. Nomear os representantes dos órgãos e entidades abaixo relacionados para comporem o Fórum Estadual Permanente de Apoio à Formação Docente em Mato Grosso do Sul - FÓRUM - MS. Diário Oficial de Mato Grosso do Sul, Campo Grande, v. 31, n. 7.568 , p. 13, 22 out. 2009.

MÉSZÁROS, I. O conceito de dialética em Lukács. São Paulo: Boitempo, 2013. 


\section{NUCCI, L. P. O Plano Nacional de Formação de Professores da Educação}

Básica (PARFOR): desafios na implementação do regime de colaboração em Mato Grosso do Sul. 2013. Dissertação (Mestrado em Educação)-Universidade Federal de Mato Grosso do Sul, Campo Grande, 2013.

PANIAGO, M. C. S. Keynesianismo, neoliberalismo e os antecedentes da "crise" do Estado. In: PANIAGO, N. C. S. (Org.). Marx, Mészáros e o Estado. São Paulo: Instituto Lukács, 2012.

SANDRONI, P. (Org.). Novíssimo dicionário de economia. São Paulo: Best Seller, 1999.

SCHIMONEK, E. M. P. Programa Mais Educação: descompromisso do Estado, compromisso da sociedade civil. In: CONGRESSO IBERO-AMERICANO DE POLÍTICA E ADMINISTRAÇÃO DA EDUCAÇÃO, 4., 2014, Porto. Anais... Porto: 2014. Disponível em: <http://anpae.org.br/IBERO_AMERICANO_IV/GT6/ GT6_Comunicacao/ElisangelaMariaPereiraSchimonek_GT6_integral.docx.pdf $>$. Acesso em: 30 ago. 2014.

SOARES, L. T. Os custos sociais do ajuste neoliberal na América Latina. 3. ed. São Paulo: Cortez, 2009. 